University of Nebraska - Lincoln

DigitalCommons@University of Nebraska - Lincoln

Faculty Publications from the Harold W. Manter Laboratory of Parasitology

1953

\title{
On the Land Mammals of St. Lawrence Island, Alaska
}

Robert L. Rausch

Arctic Health Research Center, rausch@u.washington.edu

Follow this and additional works at: https://digitalcommons.unl.edu/parasitologyfacpubs

Part of the Parasitology Commons

Rausch, Robert L., "On the Land Mammals of St. Lawrence Island, Alaska" (1953). Faculty Publications from the Harold W. Manter Laboratory of Parasitology. 524.

https://digitalcommons.unl.edu/parasitologyfacpubs/524

This Article is brought to you for free and open access by the Parasitology, Harold W. Manter Laboratory of at DigitalCommons@University of Nebraska - Lincoln. It has been accepted for inclusion in Faculty Publications from the Harold W. Manter Laboratory of Parasitology by an authorized administrator of DigitalCommons@University of Nebraska - Lincoln. 


\section{Robert Rausch}

The mammals occurring on St. Lawrence Island represent species which are widely distributed in boreal regions. They are not well known, however, and are poorly represented in collections. In the past, some of these mammals have been regarded as being specifically distinct from closely related forms occurring on the adjacent continents. It is the purpose of this paper to present some new data on these mammals, with particular reference to their taxonomy.

Begun in the winter of 1950 , the investigation of animal-borne diseases on St. Lawrence Island has been carried on by the Animal-borne Disease Branch of the Arctic Health Research Center, located at Anchorage, Alaska. The collection of mammals has been an important part of this work, and a large volume of material has been assembled. With the exception of an occurrence of unusual mortality in walrus during 1951, reported separately by Schiller (1953), nothing of extraordinary mammalogical interest involving the marine forms has been observed.

St. Lawrence Island, of volcanic origin, is about 90 miles long. It lies in the Bering Sea about 104 miles from the nearest point on the Alaskan mainland, and 38 miles from Cape Chukotskyi, Northeast Siberia. Low mountains, few exceeding 1000 feet in altitude, cover nearly half the total surface of the island. Steep cliffs, the nesting places of great numbers of sea birds, border the sea in the mountainous regions. Much of the island is low and wet, with numerous tundra ponds. Here, vegetation is characteristic of wet tundra. At higher altitudes the vegetation is typical of dry alpine tundra.

The two villages, Gambell (Sevuokuk) and Savoonga, are inhabited by about 500 Siberian Eskimo. These people depend largely upon marine mammals, particularly walrus, for food. Several hundred sledge dogs are kept by the Eskimo, but these are, in general, closely confined to the vicinity of the dwellings. About 400 reindeer range in remote parts of the island. These are descendants of animals introduced during the early part of the century; at one time the reindeer numbered more than 10,000. Poor range conditions have been largely responsible for the heavy losses which have occurred. No management program is now in force, but killing of the animals is prohibited.

Seven species of mammals are indigenous to the island; others appear from time to time via the pack ice. Species for which material or information has been obtained are considered separately:

Sorex tundrensis jacksoni, Hall and Gilmore, 1932. Tundra shrew. Shrews have been uncommon on St. Lawrence Island during the last three years, and efforts to trap them were unsuccessful. A specimen was taken by an Eskimo on January 13, 1952. Mr. Francis H. Fay, Department of Zoology, University of British Columbia, also collected a single shrew. This animal, made available to the writer, was taken on July 18, 1952, and contained seven embryos each measuring $4 \mathrm{~mm}$. in greatest length.

Sorex jacksoni was described on the basis of 16 specimens collected at Savoonga. Since the writer's material was inadequate for study, six skins and skulls were obtained on loan from the original material.

At the time of its description, $S$. jacksoni was recognized as showing a close relationship to the "Sotex arcticus group." It was differentiated from $S$. tundrensis Merriam, occurring on the Alaskan mainland, on the basis of size difference and slight relative differences in certain cranial proportions (palatal length and cranial breadth). As far as the writer can determine, the two forms are identical in characteristics of dentition. The differences as defined in the original description of $S$. jacksoni appear to have subspecific, rather than specific, value. Consequently, it is concluded that this form is more appropriately 
designated S. tundtensis jacksoni. A single form of the tundra shrew, S. t. tundrensis Merriam, is recognized on the continent. The status of the species has been discussed in some detail in another paper (Rausch, 1953).

Ursus arctos Linnaeus. Brown bear.

Geist (1934) reported the occurrence of a brown bear on St. Lawrence Island during the summer of 1933. The writer has obtained no further information on the occurrence of this species, and it must be assumed that the individual observed reached the island by way of pack ice from Siberia. The race of $U$. atctos occurring in Northeastern Siberia and Kamchatka is $U$. atctos beringianus Middendorff.

Thalarctos maritimus Phipps. Polar bear.

While never abundant around St. Lawrence Island, polar bears probably come on shore every year. Tracks are seen from time to time in the winter as on travels on the uninhabited part of the island. Bear frequently spend the summer on the island, but inhabit only the more remote regions.

The skulls of three very large old males have been obtained from Eskimo at Savoonga. The cranial measurements of these specimens are included here:

$\begin{array}{rllcccccc}\begin{array}{r}\text { Orig } \\ \text { No. }\end{array} & \text { Cbl. } & \text { Zyg. } & \begin{array}{r}\text { Inter- } \\ \text { orb. }\end{array} & \begin{array}{c}\text { Pal. } \\ \text { L. }\end{array} & \begin{array}{c}\text { Post- } \\ \text { Pal. L. }\end{array} & \begin{array}{c}\text { Squam. } \\ \text { const. }\end{array} & \begin{array}{c}\text { Mast. } \\ \text { W. }\end{array} & \begin{array}{c}\text { Max. } \\ \text { tooth } \\ \text { row }\end{array} \\ 12626 & 407.7 \mathrm{~mm} . & 256.4 & 107.3 & 198.6 & 202.3 & 169.2 & 194.9 & 139.0 \\ 12628 & 408.1 & 260.0 & 105.1 & 200.5 & 200.8 & & 198.8 & 146.7 \\ 12627 & 409.4 & 250.2 & 103.9 & 209.3 & 193.4 & 170.8 & 191.8 & 142.3\end{array}$

Canis lupus Linnaeus. Wolf.

Murie (1936) reported the occurrence of a wolf on St. Lawrence Island during 1927. The animal was not killed, but eventually disappeared. As far as can be determined, there has been no other record of this species on St. Lawrence Island. This wolf also must have arrived on the island via the pack ice. Such an occurrence would be unusual, since wolves do not range far out on the sea ice and there would consequently be little chance that they would be trapped on the moving floes.

\section{Vulpes vulpes Linnaeus. Red fox.}

Although Murie (1936) reported that red foxes are occasionally seen on the island, it has not been possible to secure any specimens. None has been trapped in recent years. According to the work of Bobrinskii et al. (1944) and that of Ellerman and Morrison-Scott (1951), the name for this form would be Vulpes vulpes Linnaeus.

The red fox is now either very rare or nonexistent on St. Lawrence Island. Although Murie (1936) had a considerable number of red fox mandibles which had been excavated from old habitation sites, he concluded also that the arctic fox (see below) "has been the dominant form." It is possible that past conditions have been such that animals came in from time to time on the pack ice and colonized the island, but they have not become permanently established. It is almost certain that such animals would come from Siberia. If such is the case, the form would be $V$. vulpes beringiana Middendorff, which, according to Ellerman and Morrison-Scott, occurs in "North-Eastern Siberia, including Kamchatka and Anadyr region." There is an obvious need for reconsideration of the red foxes of North America in light of the work of Old-World investigators who have concluded that Vulpes vulpes is a Holarctic species. 
Alopex lagopus lagopus Linnaeus. Arctic fox.

During recent years the arctic fox has been abundant on St. Lawrence Island, concurrent with a high population density of voles. One hundred six foxes have been autopsied, and a total of 38 skulls with full data has been preserved for study. In addition, some observations have been made on pelage color and molt in captive animals obtained as pups. The St. Lawrence Island arctic fox previously has not been studied in detail.

The arctic fox of St. Lawrence Island was first studied with the hope that something of the origin of one of its endoparasites, pathogenic in man, might be disclosed. These foxes are commonly infected by a tapeworm of the genus Echinococcus (Rudolphi, 1801), the larval stage of which occurs in voles (Microtus and Clethrionomys). The life cycle of this parasite has been thoroughly investigated in the laboratory, and it has been established that it differs from the form occurring in North America. Barabash-Nikiforov (1938) reported about 50 per cent of the red-backed voles, C. rutilus Pallas, infected with Echinococcus larvae on Bering Island, and Afanas'ev (1941) observed the same relationship. It has been concluded that the Bering Island-St. Lawrence Island form of Echinococcus is that which causes alveolar hydatid disease in man in south Europe and Russia (Rausch, 1952b). All such evidence supports the hypothesis that the arctic fox of St. Lawrence Island is the same form which occurs on the mainland of Siberia.

Skulls of the subspecies of arctic fox which occur in Siberia, Alaska, and on the arctic islands, have been obtained for comparative study. Unfortunately, large series of $A$. lagopus lagopus from the Siberian mainland are not available, but the skulls of four specimens of arctic fox from Nizhne-Kolymsk and one from the mouth of the Lena River, were obtained. Skulls of $A$. lagopus beringensis Merriam, $A$. lagopus pribilofensis Merriam, and $A$. lagopus innuitus Merriam were also compared.

Regarding the status of the St. Lawrence Island fox, Murie (1936; p. 339) stated, "Considering the apparent ease with which foxes can and do immigrate to St. Lawrence Island on floating ice, it is not likely that an insular form peculiar to that island is to be found. Proximity to Siberia would suggest specific affinity with the Siberian foxes." It is evident that currents in Bering Sea are such that ice and other objects (carcasses of marine mammals, etc.) are carried from Siberia to the shores of the island. The writer has not been able to differentiate the St. Lawrence Island form from the Siberian form on the basis of cranial characteristics. The obvious conclusion is that they are all of the same subspecies, $A$. lagopus lagopus.

It is also desirable to clarify the relationships of the St. Lawrence Island form to that occurring in mainland Alaska. Several subspecies of arctic fox were defined by Merriam. He described $A$. lagopus hallensis (Hall Island) in 1900, and $A$. lagopus pribilofensis (Pribilof Islands), $A$. lagopus beringensis (Bering Island), and $A$. lagopus innuitus (arctic Alaska), in 1902. In attempting to evaluate relationships, it is first necessary to gain some understanding of Merriam's species-concept insofar as these animals are concerned. This is best exemplified by his interpretation of material from the Pribilof Islands.

Merriam (1902; p. 168) recognized three "forms" of arctic fox on St. Paul Island on the basis of cranial details. Unfortunately, the number of skulls studied was not stated. Merriam considered three possibilities regarding these forms: "(1) that the large skulls represent a large resident species while the two others are stragglers from St. Matthew (or some other) Island and the mainland respectively, reaching the Pribilofs by means of the pack ice; (2) that the large skulls represent a large resident species; the small ones 
stragglers from St. Matthew (or some other) Island, while the middle sized ones are hybrids between the two; (3) that all three belong to a single species which presents extraordinary and unprecedented variations in size." Merriam accepted the second hypothesis and named the large form $V$ ulpes pribilofensis (=A. lagopus pribilofensis).

In considering the races of the arctic fox, it must be kept in mind that isolation of any insular population is impossible. These animals travel far from land upon the sea ice, and are carried great distances on ice floes. Merriam stated that arctic foxes come ashore on the Pribilof Islands whenever the pack ice extends that far south. It is well known that foxes are often transported in this manner to St. Lawrence Island, and the same must hold true for Hall, St. Matthew, and Bering Islands. It is obvious, then, that these islands might receive animals from any islands lying farther north, as well as from both continents. Regardless of origins, it is evident that new animals arrive every year on the northern islands, and less frequently on the Pribilofs, which lie relatively far to the south.

A large form on the Pribilof Islands would not maintain its genetic identity by selective breeding in the presence of animals representing other forms; the population would consist of the product of the inbreeding of such forms as were present. In the writer's opinion, Merriam's third hypothesis is the only one that could be considered valid; that is, the Pribilof Island foxes show much individual variation in size, as do all populations of the arctic fox. Material at hand does not permit final conclusion as to whether $A$. lagopus pribilofensis is distinctive, but further study involving adequate material probably will disclose that it is not. The name assigned by Merriam will have to be retained until such study has been completed.

It is significant that only two forms of arctic fox are recognized on the Siberian side of Bering Straits; these are $A$. lagopus lagopus, which ranges from Norway to Northeast Siberia, and the insular $A$. lagopus beringensis.

A large series of arctic fox skull have been collected from arctic Alaska. Included are 17 skulls from Point Barrow, the type locality of $A$. lagopus innuitus. About 20 specimens were obtained at Wainwright; several were secured at Wales, Pt. Lay, and farther inland. With these specimens as with all others studied, a high degree of individual and age variation in cranial characters is evident. Variation is noted particularly in actual size, length and width of rostrum, degree of development of median frontal sulcus, degree of inflation of frontal and temporal-parietal regions, and in size of teeth.

Merriam (1902; p. 170) differentiated $A$. lagopus innuitus from $A$. lagopus lagopus as follows: "Similar to lagopus in size and general characters, but braincase broader and more pyriform, and tapering much more abruptly behind broadest part; nasals much broader." Comparison of topotype specimens with the five specimens from Siberia has disclosed no differences. Shape of braincase is quite variable. There was no difficulty in finding Alaskan specimens in which the width of the nasal bones was exceeded by the Siberian specimens. On the basis of direct examination, it was not possible to distinguish $\vec{A}$. lagopus innuitus.

Comparisons with the St. Lawrence Island material led to the same conclusion. Since material in this case was adequate, series of the two nominal forms were compared statistically. To do this, a series of male and a series of females from St. Lawrence Island and the arctic coast of Alaska (Pt. Barrow and Wainwright only) were selected at random. Since both series had been collected at a time when the population was very high and during the same months of the year, they were considered comparable in regard to age composition without selection for adult specimens. The male and female series 
from St. Lawrence Island were paired at random with the corresponding series from the arctic coast. Statistical analysis (see Table I) failed to disclose significant differences in any of the nine characters compared.

A. lagopus innuitus cannot be distinguished from the form which occurs on St. Lawrence Island. Since all evidence supports the opinion that the St. Lawrence Island form is identical from $A$. lagopus lagolpus of Eurasia, it follows that a single, highly variable form of arctic fox has circumpolar distribution.

Other pertinent data are included in Table II.

\section{TABLE I}

Comparison of cranial measurements of randomly-paired groups of skulls of arctic foxes from St. Lawrence Island and mainland Alaska.

\begin{tabular}{|c|c|c|c|c|c|c|c|c|}
\hline \multirow{2}{*}{$\begin{array}{l}\text { Measurement } \\
\quad \text { (in } \mathrm{mm} .)\end{array}$} & \multicolumn{4}{|c|}{ Males } & \multicolumn{4}{|c|}{ Females } \\
\hline & $\begin{array}{c}\text { No. } \\
\text { Pairs }\end{array}$ & $\begin{array}{l}\text { Mean } \\
\text { diff.* }\end{array}$ & $\begin{array}{l}\text { Std. error } \\
\text { mean diff. }\end{array}$ & $t$ & $\begin{array}{l}\text { No. } \\
\text { Pairs }\end{array}$ & $\begin{array}{l}\text { Mean } \\
\text { diff.* }\end{array}$ & $\begin{array}{l}\text { Std. error } \\
\text { mean diff. }\end{array}$ & $t$ \\
\hline $\begin{array}{l}\text { Condylobasal } \\
\text { length } \\
\text { Zygomatic }\end{array}$ & 16 & .235 & 1.507 & .1500 & 20 & .134 & 1.470 & .091 \\
\hline & 17 & .170 & .602 & .2833 & 21 & .309 & .908 & .3409 \\
\hline & 17 & .200 & .362 & .5520 & 21 & .538 & .393 & $1.370^{* *}$ \\
\hline $\begin{array}{c}\text { length } \\
\text { Post-palatal }\end{array}$ & 16 & .350 & .825 & .4242 & 21 & .404 & .915 & .4424 \\
\hline $\begin{array}{l}\text { length } \\
\text { Squamosal }\end{array}$ & 14 & .371 & .917 & .4050 & 20 & .550 & .835 & .6590 \\
\hline $\begin{array}{l}\text { constriction } \\
\text { Maxillary }\end{array}$ & 16 & .425 & .744 & .5712 & 21 & .133 & .554 & .7600 \\
\hline $\begin{array}{l}\text { tooth row } \\
\text { length }\end{array}$ & 17 & .476 & .627 & .2401 & 21 & .027 & .619 & .4384 \\
\hline Nasal length & 16 & .076 & .711 & .1070 & 21 & .012 & .914 & .1354 \\
\hline Nasal width & 16 & .000 & .000 & .000 & 21 & .018 & .232 & .0780 \\
\hline
\end{tabular}

*All values of $t$ under 1.00 are associated with probability greater than 30 per cent; values under 0.70 , with probability greater than 50 per cent.

$* *_{t}$ equals $1.47: 20 \% \rightarrow \mathrm{P} \rightarrow 10 \%$.

\section{TABLE II}

Average cranial measurements of arctic foxes from St. Lawrence Island and mainland Alaska. (in millimeters)

\begin{tabular}{|c|c|c|c|c|c|c|c|c|c|c|}
\hline No. & Sex & $\begin{array}{c}\text { Condylo- } \\
\text { basal } \\
\text { length }\end{array}$ & $\begin{array}{l}\text { Zygo- } \\
\text { matic } \\
\text { width }\end{array}$ & $\begin{array}{l}\text { Inter- } \\
\text { orbital } \\
\text { width }\end{array}$ & $\begin{array}{l}\text { Palatal } \\
\text { length }\end{array}$ & $\begin{array}{l}\text { Post- } \\
\text { palatal } \\
\text { length }\end{array}$ & $\begin{array}{l}\text { Squamo- } \\
\text { sal con- } \\
\text { striction }\end{array}$ & $\begin{array}{l}\text { Maxillary } \\
\text { tooth row } \\
\text { length }\end{array}$ & $\begin{array}{c}\text { Nasal } \\
\text { length }\end{array}$ & $\begin{array}{l}\text { Nasal } \\
\text { width }\end{array}$ \\
\hline \multicolumn{11}{|c|}{ St. Lawrence Island } \\
\hline $\begin{array}{l}21 \\
17\end{array}$ & $\begin{array}{l}\mathbf{f} \\
\mathbf{m}\end{array}$ & $\begin{array}{l}117.8 \\
123.8\end{array}$ & $\begin{array}{l}65.8 \\
68.7\end{array}$ & $\begin{array}{l}26.9 \\
27.6\end{array}$ & $\begin{array}{l}60 \\
62.3\end{array}$ & $\begin{array}{l}56.3 \\
58.3\end{array}$ & $\begin{array}{l}41.8 \\
43.9\end{array}$ & $\begin{array}{l}54.5 \\
60.3\end{array}$ & $\begin{array}{l}43.6 \\
45.1\end{array}$ & $\begin{array}{l}10.1 \\
10.9\end{array}$ \\
\hline \multicolumn{11}{|c|}{ Mainland Alaska } \\
\hline $\begin{array}{l}26 \\
21\end{array}$ & $\begin{array}{l}\mathrm{f} \\
\mathrm{m}\end{array}$ & $\begin{array}{l}118.1 \\
121.8\end{array}$ & $\begin{array}{l}65.8 \\
68.5\end{array}$ & $\begin{array}{l}26.4 \\
27.4\end{array}$ & $\begin{array}{l}60.6 \\
62.6\end{array}$ & $\begin{array}{l}53.6 \\
57.4\end{array}$ & $\begin{array}{l}42.8 \\
43.1\end{array}$ & $\begin{array}{l}54.7 \\
56.2\end{array}$ & $\begin{array}{l}43.3 \\
45.4\end{array}$ & $\begin{array}{l}10.9 \\
11.1\end{array}$ \\
\hline
\end{tabular}


Citellus undulatus lyratus Hall and Gilmore. Ground squirrel.

Ground squirrels have been rather common on St. Lawrence Island during the time of our work. The skulls of 85 specimens were preserved for study.

Citellus undulatus, the long-tailed suslik, is widely distributed in Asia and boreal North America. The taxonomy and distribution of the Alaskan subspecies have been discussed in another paper (Rausch, 1953). Ognev (1947) has discussed the Siberian forms in detail. Hall and Gilmore (1932) based their description of Citellus lyratus on seven specimens collected along the north coast of St. Lawrence Island. These writers concluded that the most nearly related form is C. buxtoni Allen ( $=C$. undulatus leucostictus Brandt), of northeastern Siberia. Seven skulls of the latter, from East Cape, and Emma Harbor, Siberia, were available to the writer for comparison. Some cranial measurements of the two forms are shown in Table III.

Of the 85 specimens mentioned above, all of which were collected in August, 1950, 46 were males and 39 were females. The majority was comprised of young of the year. Forty-two males ranged in weight from 286 to 586 grams (av. 449.0 grams), and 30 females ranged from 344 to 532

\section{TABLE III}

Cranial measurements of Citellus undulatus from St. Lawrence Island and Northeast Siberia. (in millimeters)

\begin{tabular}{|c|c|c|c|c|c|c|c|c|c|c|c|}
\hline $\mathrm{Se}$ & & $\begin{array}{l}\text { ondylo- } \\
\text { basal } \\
\text { length }\end{array}$ & $\begin{array}{l}\text { Zygo- } \\
\text { matic } \\
\text { width }\end{array}$ & $\begin{array}{l}\text { Inter- } \\
\text { orbital } \\
\text { width }\end{array}$ & $\begin{array}{l}\text { Palatal } \\
\text { length }\end{array}$ & $\begin{array}{l}\text { Post- } \\
\text { palatal } \\
\text { length }\end{array}$ & $\begin{array}{l}\text { Length } \\
\text { palatal } \\
\text { foramen }\end{array}$ & $\begin{array}{l}\text { Nasal } \\
\text { length }\end{array}$ & $\begin{array}{l}\text { Squamo- } \\
\text { sal con- } \\
\text { striction }\end{array}$ & $\begin{array}{l}\text { Mas- } \\
\text { toid } \\
\text { width }\end{array}$ & $\begin{array}{c}\text { Maxillary } \\
\text { tooth row } \\
\text { length }\end{array}$ \\
\hline \multicolumn{12}{|c|}{ Citellus undulatus lyratus } \\
\hline & $\mathrm{f}$ & $\begin{array}{l}52.6 \\
52.3 \\
51.9 \\
51.7 \\
50.7 \\
49.8\end{array}$ & $\begin{array}{l}36.4 \\
35 \\
34.6 \\
34.7 \\
33.3 \\
32.4\end{array}$ & $\begin{array}{l}12.5 \\
12.6 \\
12 \\
12.2 \\
12 \\
11.4\end{array}$ & $\begin{array}{l}28.5 \\
28.7 \\
28.6 \\
28.2 \\
29.6 \\
28.5\end{array}$ & $\begin{array}{l}21 \\
20.9 \\
20.5 \\
20.2 \\
18.5 \\
18.5\end{array}$ & $\begin{array}{l}3.9 \\
3.8 \\
3.7 \\
3.9 \\
4.1\end{array}$ & $\begin{array}{l}20.3 \\
19.6 \\
19.1 \\
19.2 \\
18.7 \\
18.3\end{array}$ & $\begin{array}{l}22.8 \\
2.2 \\
21.9 \\
21.9 \\
22.1 \\
21.7\end{array}$ & $\begin{array}{l}24.2 \\
23.5 \\
23.5 \\
23.1 \\
23.1 \\
22.5\end{array}$ & $\begin{array}{l}11.5 \\
11.8 \\
12 \\
12.5 \\
12.7 \\
12.5\end{array}$ \\
\hline & m & $\begin{array}{l}54.2 \\
52.9 \\
52.7 \\
52.1 \\
52 \\
50.5\end{array}$ & $\begin{array}{l}36.7 \\
34 \\
34.5 \\
33.1 \\
33.8 \\
32.6\end{array}$ & $\begin{array}{l}13.3 \\
12.2 \\
12.5 \\
12.1 \\
12.1 \\
11.4\end{array}$ & $\begin{array}{l}29.8 \\
31 \\
30 \\
30.1 \\
30.2 \\
29.5\end{array}$ & $\begin{array}{l}21.7 \\
19.4 \\
20 \\
19 \\
19.5 \\
18.4\end{array}$ & $\begin{array}{l}3.9 \\
4 \\
4 \\
4.1 \\
4.5 \\
3.9\end{array}$ & $\begin{array}{l}20.7 \\
20.5 \\
19.3 \\
20.2 \\
19\end{array}$ & $\begin{array}{l}22.8 \\
22.8 \\
22.9 \\
22.9 \\
22.3 \\
21.7\end{array}$ & $\begin{array}{l}24.6 \\
23.8 \\
24 \\
24 \\
23.8 \\
22.7\end{array}$ & $\begin{array}{l}12.1 \\
12.5 \\
12.8 \\
12.6 \\
12.2 \\
12\end{array}$ \\
\hline $\begin{array}{l}\text { v. } \\
\text { v. }\end{array}$ & & $\begin{array}{l}51.5 \\
52.4\end{array}$ & 34.4 & $\begin{array}{l}12.1 \\
12.3\end{array}$ & & & & $\begin{array}{l}19.2 \\
19.9\end{array}$ & & $\begin{array}{l}23.3 \\
23.8\end{array}$ & $\begin{array}{l}12.2 \\
12.4\end{array}$ \\
\hline \multicolumn{12}{|c|}{ Citellus undulatus leucostictus } \\
\hline & f & $\begin{array}{l}51.7 \\
51.4 \\
51.3 \\
51.1\end{array}$ & $\begin{array}{l}35.8 \\
36.4 \\
36.8 \\
35.5\end{array}$ & $\begin{array}{l}12.1 \\
12.4 \\
13.3 \\
12.5\end{array}$ & $\begin{array}{l}31 \\
29.9 \\
30.5 \\
30.3\end{array}$ & $\begin{array}{l}20 . \\
20 . \\
20 . \\
19 .\end{array}$ & 37 & $\begin{array}{l}19.9 \\
19.2 \\
20.3 \\
19.5\end{array}$ & $\begin{array}{l}22.3 \\
22.2 \\
22.3\end{array}$ & $\begin{array}{l}24.5 \\
23.2 \\
23.9 \\
23.6\end{array}$ & $\begin{array}{l}11.8 \\
12.5 \\
12.1 \\
11.4\end{array}$ \\
\hline \multirow{2}{*}{\multicolumn{2}{|c|}{$\mathrm{m}$}} & 54 & 37.3 & \multirow{2}{*}{$\begin{array}{l}12.1 \\
13.1 \\
11\end{array}$} & 32.1 & 21.8 & 4 & \multirow{2}{*}{$\begin{array}{l}20 \\
20.6 \\
18.6\end{array}$} & 22.6 & 23.4 & \multirow[t]{2}{*}{$\begin{array}{l}12.2 \\
12.5\end{array}$} \\
\hline & & $47.9 *$ & 30.5 & & 31.3 & 17.2 & 3.7 & & 22 & 23.1 & \\
\hline v. & $\begin{array}{lr}\mathrm{f} & 5 \\
\mathrm{~m} & 5\end{array}$ & $\begin{array}{l}51.4 \\
50.9\end{array}$ & $\begin{array}{l}36.1 \\
33.9\end{array}$ & $\begin{array}{l}12.6 \\
12.1\end{array}$ & $\begin{array}{l}30.6 \\
31.7\end{array}$ & 18.5 & $\begin{array}{l}3.6 \\
3.8\end{array}$ & $\begin{array}{l}19.8 \\
19.7\end{array}$ & $\begin{array}{l}22.3 \\
22.3\end{array}$ & $\begin{array}{l}23.8 \\
23.2\end{array}$ & $\begin{array}{l}11.9 \\
12.3\end{array}$ \\
\hline
\end{tabular}

*Immature animal. 
grams (av. 434.0 grams). Twelve animals ranged in weight from 600 to 800 grams, while one was too badly damaged by the shot to be weighed. No pregnant females were included in this series, since breeding occurs only in early spring.

Dicrostonyx torquatus exsul Allen. Varying lemming.

Only two specimens of this lemming have been obtained from St. Lawrence Island in more than three years, and it is evident that it has been at a very low level of population density. Allen (1919) based his description of $D$. exsul on four specimens collected by Joseph Dixon in 1913, and there is no recent information that this form ever becomes very abundant. On the other hand, Nelson (1887) stated, regarding Cuniculus torquatus ( $=D$. torquatus): "On St. Lawrence Island and the Bering Straits Islands and adjacent coasts it is very common."

When $D$. exsul was described, available material for comparative study was inadequate to establish degree of relationship of this form with those of the adjacent continents. The writer has had for study but five specimens of this lemming, but a great deal more information is now available regarding the others. The work of Ognev (1950), who has concluded that a single Holarctic species exists, is particularly significant. On the basis of comparisons with a great deal of Alaskan material, and with limited material from Siberia, it is evident that such slight cranial differences as exist have no specific value. Allen $(1919 ;$ p. 533) called attention to the paleness of color in this form, a character of value at the subspecific level. D. torquatus exsul is paler than D. torquatus rubricatus (Richardson), of mainland Alaska, and its colors are very much subdued in comparison with $D$. torquatus lenae Kerr, of eastern Siberia. Apparently the winter pelage of the St. Lawrence Island form has not been observed previously; one of our specimens was taken in winter, and it showed the characteristic white pelage and highly-developed snow claw.

The form was designated $D$. groenlandicus exsul by Rausch (1952a), but in a more recent paper (Rausch, 1953), the species name $D$. torquatus was applied in agreement with the Old-World investigators.

Clethrionomys rutilus albiventer $\mathrm{Hall}$ and Gilmore. Red-backed vole.

The red-backed vole was also difficult to collect during the time of our work, and only four specimens were obtained. This vole was described by Hall and Gilmore (1932) on the basis of three specimens collected at Savoonga. At the time of its description, this form was considered specifically distinct. Apparently no additional specimens have been collected until recently, and the form has not been studied further.

Rausch (1950) revised the status of the red-backed voles specifically designated as C. dawsoni Merriam, and concluded that it is conspecific with C. tutilus Pallas, previously regarded as Palaearctic in distribution. For lack of material, C. albiventer was not considered. More recently, Rausch (1952a) applied the name $C$. rutilus albiventer to the St. Lawrence Island form. Hall and Cockrum $(1953 ;$ p. 385$)$ retained the original name. In regard to its affinities, however, they stated, "Closely related to $C$. tutilus, but skull larger." It is true that this is one of the largest, if not the largest, form of C. rutilus. In this regard, it is analogous to the St. Lawrence Island tundra vole, Mictotus oeconomus innuitus Merriam, discussed below. In the writer's opinion, larger size alone does not constitute specific difference.

Hall and Gilmore compared their specimens with $C$. rutilus jacutensis Vinogradov, of the Iakutsk region, Siberia, and concluded that it differed from this form in having ".. the palatal bridge less complete and the anterior, re-entrant angle of $\mathrm{m}^{3}$ shallower." Minor external and cranial differences 
were described as a result of comparisons with $C$. dawsoni (= C. tutilus dawsoni). Color characteristics were also defined.

In addition to the writer's material, three additional skulls of C. rutilus albiventer were examined. It is evident that the skull of the St. Lawrence Island form is more massive that that of the mainland C. tutilus dawsoni or the northeastern Siberian C. rutilus jochelsoni Allen; again, in this respect, it is analogous to the St. Lawrence Island tundra vole. Cranial differences, however, are not sufficient to distinguish it specifically.

The St. Lawrence Island form is rather pale dorsally, but in paleness it does not approach some of the central Asiatic races. C. tutilus albiventer is white ventrally. In the same local populations of C. rutilus dawsoni, individuals may be either white or buffy ventrally.

Microtus oeconomus innuitus Merriam. Tundra vole.

Tundra vole populations had attained a high density by the summer of 1949. This abundance of voles persisted at least through 1951. Only winter observations were made during 1952, so that any accurate evaluation of the status of this animal could not be made. About 600 specimens of this vole were obtained, of which 585 were used in parasite studies (Rausch, 1952a). Merriam (1900; p. 21) described this vole on the basis of 12 skulls taken from food pellets regurgitated by owls or jaegers. It was recognized by Zimmermann (1942) as a subspecies of $M$. oeconomus Blasius. Insofar as the writer is aware, this vole has not been studied in detail except as mentioned above.

Some data on size were recorded on a series of 84 individuals collected during August, 1950. Of these, 23 females ranged in weight from 60 to 96 grams (av. 71 grams), and 12 males ranged from 60 to 91 grams (av. 75.4). As an example of adult external dimensions, a male collected April 23, 1950, weighing 84.5 grams, measured: Total length, $190 \mathrm{~mm}$; tail, $43 \mathrm{~mm}$; hind foot length, $25 \mathrm{~mm}$. A 60 -gram female, collected the same date, measured: Total length, $172 \mathrm{~mm}$.; tail, $42 \mathrm{~mm}$.; hind foot, $23 \mathrm{~mm}$. Skull measurements of ten adult voles included in Table IV.

TABLE IV

Cranial measurements of Microtus oeconomus innuitus. (in millimeters)

\begin{tabular}{|c|c|c|c|c|c|c|c|c|}
\hline Sex & $\begin{array}{l}\text { Weight } \\
\text { (grams) }\end{array}$ & $\begin{array}{c}\text { Condylo- } \\
\text { basal } \\
\text { length }\end{array}$ & $\begin{array}{l}\text { Zygo- } \\
\text { matic } \\
\text { width }\end{array}$ & $\begin{array}{l}\text { Inter- } \\
\text { orbital } \\
\text { width }\end{array}$ & $\begin{array}{l}\text { Length } \\
\text { palatal } \\
\text { foramen }\end{array}$ & $\begin{array}{l}\text { Nasal } \\
\text { length }\end{array}$ & $\begin{array}{l}\text { Lamb- } \\
\text { doidal } \\
\text { width }\end{array}$ & $\begin{array}{l}\text { Maxillary } \\
\text { tooth row } \\
\text { length }\end{array}$ \\
\hline f & $\begin{array}{l}96 \\
82 \\
72 \\
75 \\
60 \\
70\end{array}$ & $\begin{array}{l}30.9 \\
30.5 \\
30.3 \\
29.9 \\
28.9 \\
28.6\end{array}$ & $\begin{array}{l}17.8 \\
17.8 \\
18.2 \\
17.8 \\
16.4 \\
17\end{array}$ & $\begin{array}{l}4.1 \\
4.3 \\
4.2 \\
4.3 \\
4.1 \\
4.3\end{array}$ & $\begin{array}{l}5.4 \\
5.5 \\
5.8 \\
5.4 \\
5.1 \\
5.2\end{array}$ & $\begin{array}{l}8.8 \\
9 \\
9 \\
8.7 \\
8 \\
8.5\end{array}$ & $\begin{array}{l}13.6 \\
13.3 \\
13.9 \\
13.6 \\
12.5 \\
12.7\end{array}$ & $\begin{array}{l}7 \\
7 \\
7.2 \\
7 \\
6.8 \\
6.8\end{array}$ \\
\hline $\mathbf{m}$ & $\begin{array}{r}86 \\
78 \\
\text { over } 60 \\
80 \\
65 \\
68\end{array}$ & $\begin{array}{l}32 \\
31.8 \\
30.5 \\
30.4 \\
29.4 \\
29.3\end{array}$ & $\begin{array}{l}18.9 \\
18 \\
17.1 \\
18 \\
16.3 \\
16.8\end{array}$ & $\begin{array}{l}4.4 \\
4.5 \\
4.4 \\
4.3 \\
4.6 \\
4.2\end{array}$ & $\begin{array}{l}5.8 \\
4.6 \\
5.4 \\
4.6 \\
5 \\
3.7\end{array}$ & $\begin{array}{l}9.6 \\
8.7 \\
9 \\
9 \\
8.5 \\
8.3\end{array}$ & $\begin{array}{l}14.6 \\
14.5 \\
13.6 \\
13.7 \\
13 \\
13.1\end{array}$ & $\begin{array}{l}6.9 \\
7.3 \\
6.7 \\
6.8 \\
6.9 \\
6.7\end{array}$ \\
\hline $\begin{array}{l}A v \\
A v\end{array}$ & $\begin{array}{ll}\text { erage } & \mathrm{f} \\
\text { erage } & \mathrm{m}\end{array}$ & $\begin{array}{l}29.8 \\
30.6\end{array}$ & $\begin{array}{l}17.5 \\
17.5\end{array}$ & $\begin{array}{l}4.2 \\
4.4\end{array}$ & $\begin{array}{l}5.4 \\
4.1\end{array}$ & $\begin{array}{l}7.5 \\
8.9\end{array}$ & $\begin{array}{l}13.3 \\
13.8\end{array}$ & $\begin{array}{l}6.9 \\
6.9\end{array}$ \\
\hline
\end{tabular}




\section{Acknowledgements}

This opportunity is taken to thank the following persons who have aided in making this work possible: Dr. David H. Johnson, Division of Mammals, U. S. National Museum, and Dr. Charles P. Lyman, Museum of Comparative Zoology, Harvard College, provided Palaearctic fox material; Dr. Frank Pitelka, Museum of Vertebrate Zoology, University of California, loaned the specimens of Sorex jacksoni; Mr. E. L. Schiller, of this laboratory, has done much of the field work on St. Lawrence Island, and is responsible for the collection of much of the material; Miss Reggie V. Sacressen, of this laboratory, provided much technical assistance; Mr. Edward S. Weiss, chief of the Epidemiology and Biometry Branch at this Center, advised regarding the statistical analysis of the arctic fox data. The cooperation of many of the St. Lawrence Island Eskimo is also gratefuly acknowledged.

Animal-borne Disease Branch, Arctic Health Research Center, Public Health Service, Dept. of Health, Education and Welfare, Anchorage, Alaska.

\section{LITERATURE CITED}

Afanas'ev, V. P. 1941. Parazitofauna promyslovykh mlekopitaiushchikh Komandorskikh Ostrovov. Uchenie Zapiski, Ser. Biol. Nauk. 18:93-117.

Allen, G. M. 1919. The American collared lemmings (Dicrostonyx). Bull. Mus. Comp. Zool. $62: 509-542$.

Barabash-Nikiforov, I. 1938. Mammals of the Commander Islands and the surrounding sea. J. Mammal. $19: 423-429$.

Bobrinskii, N. A., B. A. Kuznetsov, and A. P. Kuziakin. 1944. Opredelitel' mlekopitaiushchikh SSSR. Moscow. $440 \mathrm{p}$.

Ellerman, J. R. and T. C. S. Morrison-Scott. 1951. Check list of Palaearctic and Indian mammals. London. 810 p.

Geist, O. W. 1934. Brown bear seen on St. Lawrence Island. J. Mammal. 15:316-317.

Hall, E. R. and E. L. Cockrum. 1953. A synopsis of the North American microtine rodents. U. Kans. Publ. 5:373-498.

and R. M. Gilmore. 1932. New mammals from St. Lawrence Island, Bering Sea, Alaska. U. Cal. Pub. Zool. 38:391-404.

Merriam, C. H. 1900. Papers from the Harriman Alaska Expedition. I. Description of twentysix new mammals from Alaska and British North America. Proc. Wash. Acad. Sci. 2:13-30.

- 1902. Four new arctic foxes. Proc. Biol. Soc. Wash. 15:167-172.

Murie, O. J. 1936. Notes on the mammals of St. Lawrence Island, Alaska. Misc. Pub. Univ. Alaska, 2, App. 3. p. 337-346.

Nelson, E. W. 1887. Report upon natural history collections made in Alaska between the years 1877 and 1881 . Washington. $337 \mathrm{p}$.

Ognev, S. I. 1947. Zveri SSSR i prilezhashchikh stran. Vol. 5. Moscow-Leningrad. 812 p.

- 1950. Zveri SSSR i prilezhashchikh stran. Vol. 7. Moscow-Leningrad. 736 p.

Rausch, R. 1950. Notes on microtine rodents from the Brooks Range, Arctic Alaska. J. Wash. Acad. Sci. 40:133-136.

1951. Notes on the Nunamiut Eskimo and mammals of the Anaktuvuk Pass region. Brooks Range, Alaska. Arctic. 4:147-195:

1952a. Studies on the helminth fauna of Alaska. XI. Helminth parasites of microtine rodents-taxonomic considerations. J. Parasit. 38:415-444.

\footnotetext{
1952b. Hydatid disease in boreal regions. Arctic. 5:157-174.

1953. On the status of some arctic mammals. Arctic. (in press.)
}

Schiller, E. L. 1953. Some observations of unusual walrus mortality. J. Mammal. (in press.)

Zimmermann, K. 1942. Zur Kenntnis von Microtus oeconomus (Pallas). Archiv. Naturgesch., N. F. 11:174-197. 